MINING

UDC 622.24 .051

B. T. Ratov ${ }^{1,3}$, Dr. Sc. (Tech.), Prof.,
orcid.org/0000-0003-4707-3322,
B. V. Fedorov1, Dr. Sc. (Tech.), Prof.,
orcid.org/0000-0002-1196-5268,
V. L. Khomenko ${ }^{2}$, Cand. Sc. (Tech.), Assoc. Prof.,
orcid.org/0000-0002-3607-5106,
A. R. Baiboz ${ }^{1}$,
orcid.org/0000-0001-6761-9797,
D. R. Korgasbekov ${ }^{1}$,
orcid.org/0000-0001-9135-4848 https://doi.org/10.33271/nvngu/2020-3/013

1 - Satbayev University, Almaty, the Republic of Kazakhstan, e-mail: ratov69@mail.ru

2 - Dnipro University of Technology, Dnipro, Ukraine, e-mail: inteldriller@gmail.com

3 - Caspian University, Almaty, the Republic of Kazakhstan

\title{
SOME FEATURES OF DRILLING TECHNOLOGY WITH PDC BITS
}

Purpose. Improving the technology of drilling wells with blade bits by establishing patterns of interaction in a pair of "cutterrock" to find out the causes the "hanging" blade bits over the central part of the bottom hole and develop recommendations for eliminating.

Methodology. The tasks were solved by a comprehensive research method, which includes analysis and synthesis of literature and patent sources, analytical studies of existing rotary drilling models to solve the problem of "hanging" of the blade bit.

Findings. It has been established that the distribution of axial load on rock cutting elements depending on the distance from the center of the blade bits is extremely uneven: the incisors located on the periphery of the bit edges experience the smallest load, and the incisors located in the central part of the bit are the most stressed.

Originality. It was shown for the first time that the "hanging" of the bit over the central part of the face is caused by the redistribution of axial load along the bit blades from the minimum value at the periphery of the blades to its sharp increase to the bit axis to compensate for the decrease in the path travelled by the bit in this zone. For the first time, it was proposed to perform blade bits with sharpened blades along a radius, and to destroy the resulting core with a special device.

Practical value. As a result of the research, recommendations have been developed for the design of a fundamentally new design of the blade bit, which will not "hang" over the central part of the face during the drilling process. This design of the blade bit can reduce the energy intensity of drilling.

Keywords: well drilling, blade bit, PDC bit, bit "hanging”, load distribution

Introduction. In modern conditions, the main volume of coreless drilling of wells is carried out by blade and roller cone bits. For a long time, blade bits were used only for drilling soft and medium strength rocks. As working elements directly destroying the bottom hole, carbide tools were used, fixed on the blades of the bit. With the creation of diamond-carbide cutters, which began to arm blade bits, the area of effective application of the latter has expanded significantly. They began to be used effectively in non-abrasive rocks of medium hardness and partially in hard rocks. Due to its high performance, blade bits, reinforced with diamond-carbide cutters, according to experts, increased their share of the global market to $60 \%$ in 2014, and are projected to reach $80 \%$ in 2020 [1]. In Russia, these figures have already been achieved. The share of PDC bits with service support in 2011 was $86 \%$, roller cone bits only $14 \%$. For comparison: the proportion of PDC bits used in 2010 was $63 \%$ [2].

It is necessary to point out the difference in terms. In English-language literature, the term PDC (polycrystalline diamond cutters) is used, while in Russian literature the abbreviation ATP (diamond-carbide plate) is more often used.

PDC bits are widely used throughout the world and show very good results. The main technical and economic indica-

(c) Ratov B. T., Fedorov B. V., Khomenko V. L., Baiboz A. R., Korgasbekov D. R., 2020 tors of drill cutting, namely, the mechanical drilling speed, penetration and durability, are about 3-4 times higher than that of the roller bits intended for low-speed drilling. These indicators were achieved when drilling soft and medium rocks, such as chalk, salts, shale, clay, aleurolite, limestone, lowabrasive sandstone. When drilling solid rock, PDC bits exhibit a mechanical speed and penetration rate twice as large as roller bits [3].

However, there are features of drilling technology, characteristic of all blade bits of the cutting type, when penetrating soft and medium hard rocks. One of these important features is the "hang" of the bit over the central part of the face. In other words, the rotating tool stops the deepening of the well for some time, the rock is slowly crushed in the center of the face, then the drilling resumes until the next "hang", and so on. Naturally, this phenomenon adversely affects the productivity of the drilling process, it was repeatedly observed during the drilling of oil and gas wells [4].

This work is devoted to the improvement of the technology of drilling wells with blade bits by establishing the patterns of interaction in a pair of cutter-rock. On the basis of this, the reasons for the "hanging" of the vane bits above the central part of the bottom of the well will be clarified and recommendations will be made to eliminate this negative phenomenon.

Literature review. To date, a huge number of works have been published on the design and development of technology 
for the use of carbide crowns. A great contribution to solving this problem was made by: G.V.Artsimovich, D.N.Bashkatov, R. K. Bogdanov，K.I. Borisov，Yu.E. Budyukov， N. N. Burenkov, V.S. Vladislavlev, B. I. Vozdvizhensky, S.A. Volkov, V. I. Vlasyuk, V. K. Volodchenko, L. K. Gorshkov, N. G. Egorov, A.P.Zakora, A. M. Isonkin, A. G. Kalinin, V.G. Kardysh, A. T. Kiselev, E. A. Kozlovsky, M. G. Krapivin, B. B. Kudryashov, N. I. Kulichikhin, Yu. F. Litkevich, L. A. Lachinyan, V. V. Neskomoromnyh, A. I. Osetsky, A.A. Pogarsky, V. M. St. Petersburg, B. M. Rebrik，S. Ya. Ryabchikov，V.I.Spirin, S.S.Sulakshin, N. V. Soloviev, N. I. Sysoev, A. F. Tretiak, V. S. Fedorov, V.F. Chihotkin, F.A.Shamshev, L.A.Schreiner, E. F.Epstein, H. Wouts, E. Halle, D. Gislin, D. Lamus, H. Fullerton, V. Mauer, and others.

At present, there exist and are being applied in practice two models of rotary drilling and, accordingly, two theories for the formation of the bottom hole in rotary drilling. The first theory is based on a model in which the processes of introducing the working element (cutter) of a rock-destruction tool and the propagation of a fracture zone over the entire surface of the bottom of a well are separated and carried out consistently. These views are shared by a large group of prominent scientists: B. I. Vozdvizhensky， I. A. Ostroushko， S. S. Sulakshin, A. N. Popov, B. V. Fedorov, and others.

The second theory is based on a model representing the drilling process as a simultaneous combination of vertical and horizontal movement of the tool. As a result of this combination, the cutter moves along a helical surface. The second theory was developed by the famous scientist Professor Vladislavlev V.S. There are far fewer supporters of this theory [5].

In article [6], to study the work of a rock cutting tool at the bottomhole, it was proposed to consider the interaction of each of its tool as an element of a single and interconnected system with the rock.

Studies of the effect of the resultant force at steady-state cutting-spitting on the depth of the tool during drilling are given in [7].

The angle of inclination of the tool is also an important design parameter. Thus, in work [8], the influence of the inclination angle of the diamond-carbide plate on the wear resistance and loading of the drilling tool was carried out. Using the method for calculating the geometrical parameters of drill bits and the corresponding computer program, the working angle parameters of the drill bit are determined.

In [9], in the course of analyzing the destruction of the rock while drilling with PDC bits, geometrical dependences of the normal cutting force and its components on the front cutting angle and area parameters drilled by the cutter were obtained. Formulas for the dependence of the pressing force of the tool on the axial and tangential components of the forces with a constant front cutting angle are obtained.

In [10], the influence of various factors on the mechanical drilling rate was analyzed. In particular, it was found that with a decrease in the inclination angle of the cutting plate, as well as with a decrease in its lateral angle of the installation, the fracture efficiency increases. Also, the drilling rate decreases with an increase in the number of incisors.

A somewhat different conclusion was made in [11], where it was stated that the average mechanical drilling speed reaches a maximum value at an inclination angle of the cutting insert $40-50^{\circ}$

Studies were carried out for two types of incisors: a conventional incisor with a sharp cutting edge and an incisor in which the cutting edge is blunted with a facet of $0.3 \mathrm{~mm}$ at an angle of $45^{\circ}$. The presence of such a chamfer, according to the authors, prevents chipping of the sharp edge. The work concluded that due to the presence of chamfer, there is a redistribution of lateral and vertical loads on the cutter. In this case, the vertical load increases, and the lateral load decreases. This increases the efficiency of the transfer of axial load on the rock cutting elements and, consequently, increases the mechanical speed of drilling. When using PDC bits with a blunt cutting edge, it is necessary to reduce the cutting angle by $5-10^{\circ} \mathrm{com}-$ pared to bits equipped with cutting tools with a sharp cutting edge [11].

The influence of the tool width on the mechanical drilling rate was also studied in [14]. In particular, when changing the width of the tool from 2 to $0.2 \mathrm{~mm}$ (i.e. by suspending it), the drilling speed increases from 7 to $56-72 \mathrm{~m} / \mathrm{h}$, depending on the influence of friction forces. It was concluded that with a decrease in the width of the tool, the axial load losses increase due to the action of friction forces, and the recess for one revolution and the mechanical drilling speed decrease more intensively.

The issue of the redistribution of axial force between the lateral and vertical components is also the subject of work [12]. To improve the efficiency and effectiveness of the cutting tool design, a new reverse engineering method is proposed based on the PDC bit geometry. The design parameters of the PDC bits (cutter parameters and the profile of the bit itself) are calculated on the basis of data obtained using 3D scanning technology. The reverse engineering method allows one to define design parameters with high accuracy.

The lateral force optimization model improves the stability of the drill bit, reducing the lateral force of the drill bit. Through optimizing the position of the circumference of each blade, the installation angle of each cutter optimizes. The proposed method is an effective technique to minimize the overall lateral force. The wear rate optimization model can effectively extend the life of the optimized bit. Due to optimization, the lateral force of the drill bit is reduced from 7.55 to $3.17 \%$, and the wear of the drill bit along the radius becomes more uniform. As a result of the production tests, the penetration of the bit increased by $23 \%$ compared with the penetration of the initial bit, and the mechanical drilling rate improved by $3.7 \%$ [12].

The article [13] presents the results of analytical and experimental studies of the dependence of the efficiency of rock destruction on the speed of movement of the cutting element. The authors indicate that if the well drilling process goes with a projected constant axial load on the bit, reducing the interaction time between the incisors and the rock at each specific point of the face to be destroyed reduces the depth (volume) of the disintegration processes in the rock monolith. Consequently, the depth of dynamic cutting of rock in any mode of destruction for a particular load is reduced.

Analyzing the basic concepts of both theories and the practical results achieved with their use, we can argue that due to the huge variety of rock properties, both of them have a right to exist and successfully explain in their field the actual processes of interaction of the working element (cutter) with the rock mass during drilling.

The first theory theoretically proved and experimentally confirmed the stages of the process of introducing the cutter into an elastic-brittle and elastic-plastic rock, the formation of a "crater" and a "hole" of destruction, the dimensions of which are larger than the corresponding dimensions of the incised cutter. The latter explains the free passage of the rockbreaking tool along the wellbore as the bottomhole deepens. The first theory has an advantage in describing the process of percussion-rotary drilling, as well as rotary drilling of hard rock, i.e. in conditions when the drilling method allows dividing the process of introducing the cutter into the face, followed by rotation or at a low drilling rate of hard rock, when it can be assumed that when the cutter is inserted and subsequently rotated, the deepening bottomhole lies in the same plane.

The second model has an undoubted advantage when drilling by cutting soft and medium hard plastic rocks. However, from the standpoint of the second model, it is impossible to explain the free passage of the rock-cutting tool after the deepening bottom of the well. The second model does not take 
into account the friction forces arising on the side surfaces of the moving tool.

Unsolved aspects of the problem. Existing theories and studies do not explain which factors and to what extent they affect the "hanging" of the blade bits and do not offer suggested measures to reduce the impact of these factors. The problem of "hanging" of the blade bit can be solved only from the point of view of the second theory, one of the basic principles of which is that the depth of the incisor is proportional to the path traveled by the said incisor. It is from this position that this phenomenon can be explained.

Purpose. Improving the technology of drilling wells with blade bits by establishing patterns of interaction in a pair of "cutter-rock" to find out the causes and develop recommendations for eliminating the "hanging" blade bits over the central part of the bottom hole.

Methods. The tasks were solved by a comprehensive research method, which includes analysis and synthesis of literature and patent sources, analytical studies of existing rotary drilling models to solve the problem of "hanging" of the blade bit.

Results. The model of interaction of the cutter of a rockdestroying tool with a rock, proposed by V. S. Vladislavlev, was improved by us taking into account the influence of the friction force arising on the front edge of the cutter of a rock-destroying tool on the true axial load, the groove per revolution and the mechanical drilling speed in $[14,15]$.

When the indenter is moved along the rock along a helical trajectory, in one revolution, the cutter travels the $x_{\text {rev }}$ path and goes deeper by $h$. The angle of inclination $\alpha$ is a line to a plane perpendicular to the axis of the well, characterized by the tangent of this angle $\operatorname{tg} \alpha$

$$
\operatorname{tg} \alpha=\frac{h}{x_{\text {rev }}} .
$$

On the other hand, V.S. Vladislavlev shows the fundamental dependence of the tangent of the angle $\alpha$ of the inclination of the helix, along which the tool's incisors move when the face deepens

$$
\operatorname{tg} \alpha=\frac{2 q_{i}}{a \delta},
$$

where $q_{i}$ is the vertical load intensity, N/m; $a$ is stiffness of a pair of indenter-rock, $\mathrm{Pa} ; \delta$ is dimension of the indenter along the line of its movement, $\mathrm{m}$.

The hardness of the indenter exceeds the rock hardness by an order of magnitude. Therefore, the indenter can be considered as an absolutely solid body, and then the rigidity of the pair will be determined only by the rigidity of the rock. Then the rock stiffness can be determined as follows

$$
a=\frac{E}{1-\mu^{2}},
$$

where $E$ is Young's modulus of rock, $\mathrm{Pa} ; \mu$ is Poisson's ratio of rock.

Taking into account the working conditions of the rock cutting tool in the drilled well

$$
q_{i}=\frac{Q}{m b},
$$

where $Q$ is the axial load on the bit, $\mathrm{N} ; m$ is the number of incisors overlapping the width of the face; $b$ is face width (along the radius), $m$.

$$
\text { Substituting (3) and (4) into (2) we get }
$$

$$
\operatorname{tg} \alpha=\frac{2 Q\left(1-\mu^{2}\right)}{b m E \delta} .
$$

Equating the value of $\operatorname{tg} \alpha$ obtained in formulas (1) and (5), and also taking into account the constrained conditions of operation of the cutters in the borehole, we get

$$
\frac{h}{x_{\text {rev }}}=\frac{2 Q\left(1-\mu^{2}\right)}{b m E \delta \lambda},
$$

where $\lambda$ is the coefficient taking into account the working conditions of the cutters in the well. According to V.S. Vladislavlev, it is equal to $\lambda=1.38$.

From here, the groove for one revolution of the bit is equal to

$$
h=x_{\text {rev }} \frac{2 Q\left(1-\mu^{2}\right)}{b m E \delta \lambda} .
$$

Mechanical drilling speed

$$
V_{m}=h n,
$$

where $n$ is bit rotation frequency, $\mathrm{s}^{-1}$

When the cutter moves along the face, overcoming the resistance of the rock, it acts with the front edge on the wall of its groove with force

$$
P=\sigma_{s h} \cdot b \cdot h_{1},
$$

where $\sigma_{s h}$ is shear rock strength, $\mathrm{Pa} ; b$ is groove width, $\mathrm{m} ; h_{1}$ is the thickness of the rock layer removed by a single cutter in the destruction of rock, $m$.

In turn,

$$
h_{1}=\frac{h}{m} .
$$

In the process of rock destruction during drilling, the cutter is affected by a static axial load Q, under the action of which the cutter moves down and deepens the rock, as well as the torque $\mathrm{M}$, under the action of which the cutter rotates around the axis of the rock-destroying tool. In this case, when the cutter moves in these two directions, friction forces arise, which are directed to the sides opposite to the movement. Since the deepening of the cutter in one revolution is small compared to the path it has traveled in one revolution around the circumference, the friction force $\tau$ acting on the front face of the cutter and directed upwards, as a rule, is neglected. However, in soft and medium rocks, with high axial loads, when the mechanical drilling speed is high, the cutter paths traversed down and along the bit circumference become comparable values. So, for these conditions, the influence of the friction force acting on the front edge of the tool to reduce the axial load should be taken into account.

In previous studies, we found that, due to the influence of this friction force, the mechanical speed when drilling with bits with rock-breaking elements with a bluntness of $0.2 \mathrm{~mm}$ can be reduced by $20-25 \%$. In addition, the proposed new analytical dependencies allow predicting the dredging in one turn and the mechanical drilling rate [14].

The friction force $\tau$ is defined as follows

$$
\tau=P f
$$

where $f$ is the coefficient of friction on the contact cutter-rock, it varies within $f=0.1-0.4$.

Thus, the true value of the axial load is

$$
Q_{a}=Q-\tau \text {. }
$$

From (8) it follows that the required axial load on the bit created on the surface to obtain the desired effect should be increased by force, taking into account (6) and (7)

$$
\tau=\frac{\sigma_{s h} b h f}{m} \text {. }
$$

These dependences make it possible to obtain the distribution of loads along the radius of the blades of the bit and to find out the cause of the periodic "hanging" of the latter.

To find out the reasons for "hanging", we divide each blade of the bit blade along its length $R_{\max }$ into the required number of equal sections (for example, into 6, as shown in Fig. 1). 


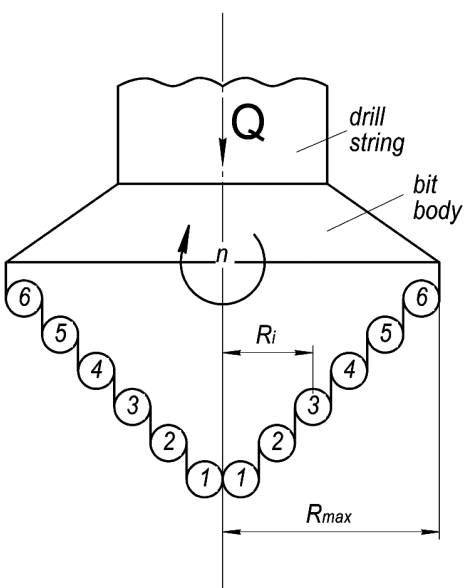

Fig. 1. Drilling scheme with a spade-shaped blade bit:

$1,2,3, \ldots, 6$-incisors; $R_{i}$ - radius of rotation of the $i^{\text {th }}$ cutter; $R_{\max }-$ maximum radius of rotation; $I, I I$ - blades

In operation, at each revolution of the bit, different sections will move in a circle, the length of which is proportional to the radius. The maximum path will be made by the incisors located at the outer edge of the chisel: the incisors located near the center run by far less time. The path of the tool located on the axis of rotation of the bit will be zero.

According to the second theory of destruction, the groove of the cutter is proportional to the path that it runs. If the aforementioned blade edge sections were in no way connected with each other, the different sections would have different depths per revolution, and the farther from the axis of rotation they were located, the larger the depth would be. However, since the chisel is a single structure, the depth for all its sections cannot be different. The same pit for cutters running through a different path is provided by the redistribution of the axial load acting on the bit.

As a result of this redistribution, the axial load on the cutting edge increases as it approaches the center of rotation. This changes the mechanism of destruction: instead of cutting, the cutter is pressed into the rock. Rock indentation resistance is greater than cutting resistance. This is the cause of the "hang" of the bit on its central part.

Suppose that a chisel has a diameter $D$, the number of blades is $N$, and on each blade there are $K$ cutting elements, counting from the axis of rotation (Fig. 1). Then the distance from the axis of rotation to an arbitrary radius $R_{i}$ of the middle of the $i^{\text {th }}$ element is determined by the formula

$$
R_{i}=0.5 b+b(i-1),
$$

where $b$ is the width of the $i^{\text {th }}$ cutting element along the blade from the axis of rotation of the clay bit. With equal length of the cutting elements

$$
b=\frac{D}{2 K} .
$$

If the total load on the bit while drilling is $Q$, then we can write

$$
Q=N \sum_{i=1}^{K} Q_{i}
$$

In [5], the following formula was obtained to determine the axial load for any cutter located on the cutting edge of the vane bit

$$
Q_{i}=h_{1}\left(\frac{E \delta \gamma}{4 \pi(i-0.5)\left(1-\mu^{2}\right)}+\frac{D \sigma_{s h} f}{2 K}\right)
$$

The thickness of the layer of rock removed by a single cutter during the destruction of the rock is defined as

$$
h_{1}=\frac{V_{m}}{n N},
$$

where $V_{m}$ is mechanical drilling speed, $\mathrm{m} / \mathrm{s}$.

Analysis of formula (10) shows that the first terms in brackets depend on the position of the cutting element on the blade, i. e. on its radius of rotation $R_{i}$, defined by the formula (9). The second term does not depend on $R_{i}$.

We define the distribution of loads $Q_{i}$ along the blade radius on a concrete example for the following initial data: $D=$ $=240 \mathrm{~mm}=0.24 \mathrm{~m} ; \sigma_{s h}=40 \mathrm{MPa}=4 \cdot 10^{7} \mathrm{~Pa} ; f=0.4 ; K=6$; $E=60000 \mathrm{MPa}=6 \cdot 1010 \mathrm{~Pa} ; \delta=0.5 \mathrm{~mm}=0.0005 \mathrm{~m} ; \mu=0.3$; $\gamma=1.38 ; V_{m}=18 \mathrm{~m} / \mathrm{h}=0.005 \mathrm{~m} / \mathrm{s} ; n=100 \mathrm{~min}^{-1}=1.67 \mathrm{~s}^{-1}$; $\mathrm{N}=4$.

Load on four blades at $R_{1}=0.010 \mathrm{~m}$ will be $Q_{1}^{4}=22682 \mathrm{~N}$.

We will perform similar calculations for other values $i$ (Fig. 1).

Results of calculations $Q_{i}$ and $Q_{i}^{4}$ are given in Table and in Fig. 2.

Analysis of Table and the graph of the function $Q_{i}^{*}=f\left(R_{i}\right)$ (Fig. 2) shows that the minimum axial load for drilling rock at a given speed, having the initial physical and mechanical properties, is on the periphery of the bit at $R_{i}=110 \mathrm{~mm}$, where $Q_{i}^{4}$ is only $3 \mathrm{kN}$. The axial load on the axis of the bit, on the contrary, reaches a large value, increasing to $25 \mathrm{kN}$, i. e. by more than 8 times. To remove this excessive load, it is advisable to eliminate several stages of the blades of the bit adjacent to the axial zone of its rotation. Such a constructive solution has pike-shaped blade bits (patents of the Republic of Kazakhstan), in which the blades (edges) near the axis of rotation are eliminated, and the design of the tool is equipped with a pilot drilling a small-diameter well. The latter then expands the shortened blades to the nominal size. However, another problem arises here associated with recommending the designation of a rational diameter of pilot wells.

If the minimum diameter of the pilot hole is $40 \mathrm{~mm}\left(R_{i}=\right.$ $=20 \mathrm{~mm}$ ), then, judging from the schedule, $Q_{i}^{4}=12 \mathrm{kN}$,

Table

The distribution of axial load on one $\left(Q_{i}\right)$ and four blades $\left(Q_{1}^{4}\right)$ along the radius of the blade of the peak

\begin{tabular}{|l|c|c|c|c|c|c|}
\hline$i$ & 1 & 2 & 3 & 4 & 5 & 6 \\
\hline$R_{i}, \mathrm{~mm}$ & 10 & 30 & 50 & 70 & 90 & 110 \\
\hline$Q_{i}, \mathrm{~N}$ & 5671 & 2050 & 1326 & 1016 & 843 & 734 \\
\hline $\begin{array}{l}\text { Load on four } \\
\text { blades, } Q_{i}^{4}, \mathrm{~N}\end{array}$ & 22682 & 8201 & 5304 & 4063 & 3374 & 2935 \\
\hline
\end{tabular}

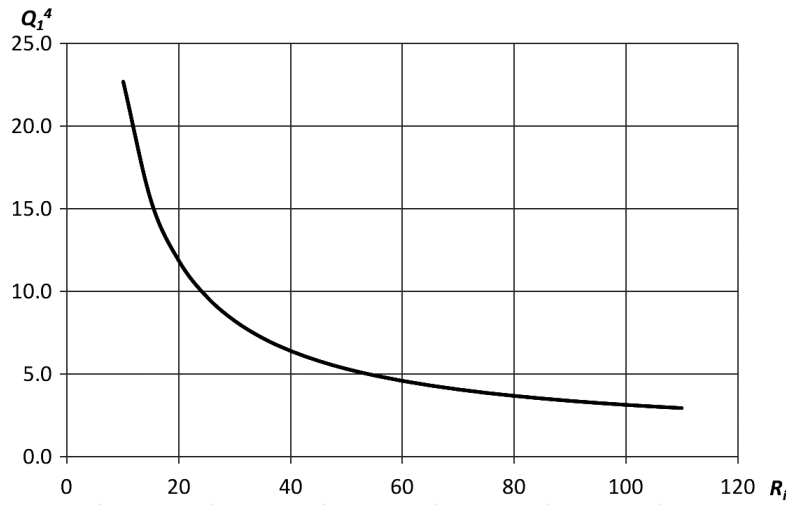

Fig. 2. Load dependence $Q_{i}^{4}$, acting on the four blades of the peak of a bit, depending on the radius of rotation $R_{i}$ cutting elements 
which is a fairly large value, which increases the energy intensity of drilling. If we take a core diameter of $80 \mathrm{~mm}\left(R_{i}=\right.$ $=40 \mathrm{~mm}$ ), then from the graph $Q_{i}^{4}=f\left(R_{i}\right)$ there follows a sharp decrease in the load $\left(Q_{i}^{*}=7 \mathrm{kN}\right)$ and the intensity of drilling. However, the drilled core will be massive enough that will cause additional problems with its destruction.

Conclusions.

1. The cause of the "hanging" of the blade bit during rotary drilling is the redistribution of axial load along the blades of the bit from the minimum value at the periphery of the blades to its sharp increase to the axis of the bit in order to compensate for the decrease in the path traveled by the cutter in this zone.

2. To eliminate the negative impact of the "hanging" of the bit, it is necessary to solve multidirectional tasks:

- drilling a pilot hole with a sufficiently small diameter: the small diameter of core drilling makes it possible to simply solve the problems of fracture of the core being formed, but it cannot relieve the excessive load acting on the part of the bit blade adjacent to its axis of rotation;

- pilot-hole drilling with an increased diameter compared to the previously examined one. With an increase in the core drilling diameter, the problem of the destruction of the core being formed becomes more complicated, but the excessive load is eliminated over the long length of the bit edges adjacent to the axis of rotation of the bit.

3. The final solution of the aforementioned contradictory task should be sought in the direction of the minimum energy intensity of drilling a well with spike-shaped blade bits.

\section{References.}

1. Yahiaoui, M., Paris, J-Y., Delbé, K., Denape, J., Gerbaud, L., \& Dourfaye, A. (2016). Independent analyses of cutting and friction forces applied on a single polycrystalline diamond compact cutter. International Journal of Rock Mechanics and Mining Sciences, (85), 20-26. https://doi.org/10.1016/j. ijrmms.2016.03.002.

2. Chulkova, V. V., \& Ganjumyan, R.A. (2014). Selection criteria for PDC bits with anti-vibration inserts. Association of Drilling Contractors Bulletin, (1), 45-48.

3. Yahiaoui, M., Paris, J-Y., Delbé, K., Denape, J., Gerbaud, L., Colin, C., Ther, O., \& Dourfaye, A. (2015). Quality and wear behavior of graded polycrystalline diamond compact cutters. International Journal of Refractory Metals and Hard Materials, (56), 87-95. https://doi.org/10.1016/j.ijrmhm.2015.12.009.

4. Bogomolov, R. M., Grinev, A. M., \& Dedov, N. I. (2016). Creation of innovative diamond bits for drilling additional sidetracks. Bulletin of the Samara Scientific Center of the Russian Academy of Sciences, 18(4), 215-219.

5. Fedorov, B. V., Khuzina, L.B., Ratov, B.T., \& Sharauova, A. B. (2017). Modeling the process of deepening a well with PDC bits. Oil and gas, (4), 77-85.

6. Neskoromnykh, V. V., \& Popova, M. S. (2018). Fundamentals of a systematic approach to the design of a drilling tool. Construction of oil and gas wells on land and at sea, (8), 26-31. 7. Oka, A. V., \& Dushko, S. R. (2017). To the study of rock destruction with bits equipped with PDC cutters. Scientific researches, 6(17), 15-17.

8. Sysoev, N. I., Burenkov, N. N., \& Hung, C. K. (2016). Justification of the structure and the selection of rational design parameters of a drill bit reinforced with diamond carbide inserts. News of higher educational institutions. North Caucasus region. Technical sciences, 2(190), 77-83. https:// doi.org/10.17213/0321-2653-2016-2-77-83.

9. Zaitsev, V. I., Karpikov, A. V., \& Che, V.V. (2014). Efficiency of use of bits PDC. Proceedings of the Siberian Branch of the Section of Earth Sciences of the Russian Academy of Natural Sciences. Geology, exploration and development of mineral deposits, 5(48), 58-66.
10. Abdul-Rani, A.M., Zamri Ismail, M., Ariff Zaky, M., Hariz, M., Noor, M., Zhun, Y.Y., Ganesan, K., Rao, T.V., V. L. N., Subhash Kamal, \& Turnad Lenggo Ginta (2014). Improving Rate of Penetration for PDC Drill Bit Using Reverse Engineering. Applied Mechanics and Materials, (607), 153-160. https://doi.org/10.4028/www.scientific.net/AMM.607.153.

11. Soloviev, N. V., Arsentiev, Yu.A., Nguyen Tien Hung, \& Kurbanov, N. Kh. (2015). A theoretical method for substantiating the design parameters of cutting-chipping bits. Scientific and Technical Journal "Oil Engineer", (3), 16-25.

12. Ai, Z., Han, Y., Kuang, Y., Wang, Y., \& Zhang, M. (2018). Optimization model for polycrystalline diamond compact bits based on reverse design. Advances in Mechanical Engineering. https://doi.org/10.1177/1687814018781494.

13. Borisov, K. I., \& Rubtsov, V. I. (2014). An analytical study of the temporary strength characteristics of rocks during cutting-chipping PDC cutters. News of Tomsk Polytechnic University, 325(1), 172-180.

14. Biletsky, M. T., Kozhevnykov, A.A., Ratov, B.T., \& Khomenko, V. L. (2019). Dependence of the drilling speed on the frictional forces on the cutters of the rock-cutting tool. Naukovyi Visnyk Natsionalnoho Hirnychoho Universytetu, (1), 2127. https://doi.org/10.29202/nvngu/2019-1/22.

15. Biletsky, M.T., Ratov, B.T., Kozhevnykov, A.A., Baiboz, A. R., \& Delikesheva, D. N. (2018). Updating the theoretic model of rock destruction in the course of drilling. News of the National Academy of Sciences of the Republic of Kazakhstan-Series of Geology and Technical Sciences, (2), 63-71.

\section{Деякі особливості технології буріння лопатевими долотами PDC}

\section{Б. Т. Ратов $^{1,3}$, Б. В. Федоров ${ }^{1}$, В. Л. Хоменко ${ }^{2}$, А. Р. Байбоз ${ }^{1}$, Д. Р. Коргасбеков ${ }^{1}$}

1 - Satbayev University, м. Алмати, Республіка Казахстан, e-mail: ratov69@mail.ru

2 - Національний технічний університет «Дніпровська політехніка», м. Дніпро, Україна, e-mail: inteldriller@ gmail.com

3 - Caspian University, м. Алмати, Республіка Казахстан

Мета. Удосконалення технології буріння свердловин лопатевими долотами шляхом установлення закономірностей взаємодії в парі «різець - порода» для виявлення причин «зависання» лопатевих доліт над центральною частиною вибою свердловини й розробки рекомендацій з їх усунення.

Методика. Поставлені завдання вирішувались комплексним методом дослідження, що включає аналіз і узагальнення літературних і патентних джерел, проведення аналітичних досліджень існуючих моделей обертального буріння для рішення задачі із «зависання» лопатевого долота.

Результати. Встановлено, що розподіл осьового навантаження на породоруйнуючі елементи в залежності від відстані від центру лопатевих доліт вкрай нерівномірний: найменше навантаження відчувають різці, що розташовані в центральній частині долота.

Наукова новизна. Уперше показано, що «зависання» долота над центральною частиною вибою викликане перерозподілом осьового навантаження по лопатям долота від мінімальної величини на периферії лопатей до його різкого зростання до осі долота, щоб компенсувати зменшення шляху, пройденого різцем у цій зоні. Уперше запропоновано виконувати лопатеві долота з укороченими по радіусу лезами, а керн, що утворюється в результаті цього, руйнувати спеціальним пристроєм.

Практична значимість. У результаті проведення досліджень розроблені рекомендації з проектування принци- 
пово нової конструкції лопатевого долота, що у процесі буріння не буде «зависати» над центральною частиною вибою. Така конструкція лопатевого долота дозволяє знизити енергоємність буріння свердловин.

Ключові слова: буріння свердловин, лопатеве долото, РDC долото, «зависання» долота, розподіл навантаження

\section{Некоторые особенности технологии бурения лопастными долотами PDC}

\section{Б. Т. Ратов $^{1,3}$, Б. В. Федоров ${ }^{1}$, В. Л. Хоменко ${ }^{2}$,} А. Р. Байбоз ${ }^{1}$, Д. Р. Коргасбеков ${ }^{1}$

1 - Satbayev University, г. Алматы, Республика Казахстан, e-mail: ratov69@mail.ru

2 - Национальный технический университет «Днепровская политехника», г. Днепр, Украина, e-mail: inteldriller@ gmail.com

3 - Caspian University, г. Алматы, Республика Казахстан

Цель. Совершенствование технологии бурения скважин лопастными долотами путем установления закономерностей взаимодействия в паре «резец - порода» для выяснения причин «зависания» лопастных долот над центральной частью забоя скважины и разработки рекомендаций по их устранению.

Методика. Поставленные задачи решались комплексным методом исследования, который включает анализ и обобщение литературных и патентных источников, проведение аналитических исследований существу- ющих моделей вращательного бурения для решения задачи о «зависании» лопастного долота.

Результаты. Установлено, что распределение осевой нагрузки на породоразрушающие элементы в зависимости от расстояния от центра лопастных долот крайне неравномерно: наименьшую нагрузку испытывают резцы, расположенные на периферии лезвий долота, наибольшая нагрузка действует на резцы, расположенные в центральной части долота.

Научная новизна. Впервые показано, что «зависание» долота над центральной частью забоя вызвано перераспределением осевой нагрузки по лопастям долота от минимальной величины на периферии лопастей до ее резкого возрастания к оси долота, чтобы компенсировать уменьшение пути, пройденного резцом в этой зоне. Впервые предложено выполнять лопастные долота с укороченными по радиусу лезвиями, а образующийся в результате керн разрушать специальным устройством.

Практическая значимость. В результате проведения исследований разработаны рекомендации по проектированию принципиально новой конструкции лопастного долота, которое в процессе бурения не будет «зависать» над центральной частью забоя. Такая конструкция лопастного долота позволяет снизить энергоемкость бурения скважин.

Ключевые слова: бурение скважин, лопастное долото, PDC долото, «зависание» долота, распределение нагрузки

Recommended for publication by O. M. Davydenko, Doctor of Technical Sciences. The manuscript was submitted 24.05.19. 